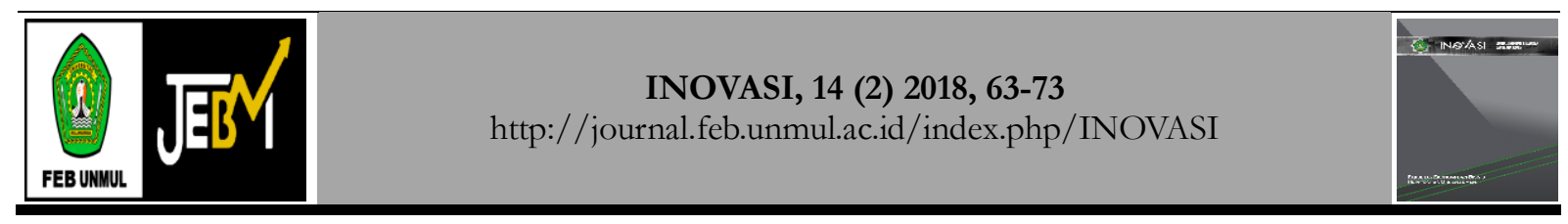

\title{
Identifikasi potensi retribusi pasar dalam upaya peningkatan pendapatan asli daerah kota samarinda
}

\author{
Bramantyo Adi Nugroho ${ }^{1}$, Puput Wahyu Budiman² \\ Badan Penelitian dan Pengembangan Daerah Provinsi Kalimantan Timur, Jalan M.T. Haryono No. \\ 126, Samarinda, Kalimantan Timur 75124, Indonesia. \\ ${ }^{1}$ E-mail: bramantyo@kaltimprov.go.id \\ ${ }^{2}$ Email: puput_wb@kaltimprov.go.id
}

\begin{abstract}
Abstrak
Tujuan dari penelitian ini untuk mengidentifikasi kontribusi dan potensi penerimaan dari retribusi pasar yang meliputi Retribusi Pelayanan Pasar dan Retribusi Pemakaian Tempat Berjualan di Pasar Tradisional di kawasan pasar Kota Samarinda, mengidentifikasi hambatan dalam pemungutan retribusi pasar di kawasan pasar Kota Samarinda dan memberikan solusi terhadap hambatan dalam pemungutan retribusi pasar di Kawasan pasar Kota Samarinda. Metode penelitian yang digunakan adalah metode penelitian deskriptif evaluatif dengan alat analisis kontribusi sesuai dengan Kepmendagri Nomor 690.900.327 dan Analisis Potensi Pasar. Rentang data yang digunakan antara tahun 2012-2017 dan data jumlah ruko, kios, petak, los pada 12 pasar di Kota Samarinda. Berdasarkan hasil perhitungan analisis kontribusi antara tahun 2012-2017 kontribusi Retribusi Pelayanan Pasar terhadap Pendapatan Asli Daerah Kota Samarinda memiliki kriteria Sangat Kurang karena nilainya masih dibawah 10 persen. Potensi Retribusi Pelayanan Pasar yang dikelola oleh Dinas Perdagangan Kota Samarinda adalah sebesar Rp. 6.58 Miliar/tahun. Potensi Retribusi Tempat Berjualan Di Lingkungan Pasar Tradisional sebesar Rp. 1.34 Miliar/tahun. Sesuai dengan hasil survei dan wawancara maka diperoleh tiga hambatan utama yang menjadikan pemungutan retribusi pasar tidak optimal yaitu kendala cuaca, pedagang tidak berjualan dan sarana prasarana yang kurang baik.
\end{abstract}

Kata Kunci: Pendapatan asli daerah; retribusi pelayanan pasar; retribusi pemakaian tempat berjualan di lingkungan pasar tradisional

\section{Identification of potential market retribution in improvement efforts original local revenue of samarinda city}

\begin{abstract}
The purpose of this study to identify the contribution of revenue and potential revenue from market retribution which includes Market Service Retribution and Selling Place Usage Retribution in the Market Traditionally in the Kota Samarinda market area, it identifies barriers in collecting market fees in the Samarinda City market area and provides solutions to obstacles in collecting market retribution in the Samarinda City Market area. The research method used is descriptive evaluative research method with contribution analysis tools in accordance with the Ministry of Home Affairs Decree No. 690,900,327 and Market Potential Analysis. The data range used between 2012-2017 and data on the number of shop houses, kiosks, plots, stalls in 12 markets in Samarinda City. Based on the calculation of the contribution analysis between 2012-2017 the contribution of the Market Service Retribution to the Local Original Revenue of Samarinda City has a Very Less criteria because the value is still below 10 percent. Potential Market Service Retributions managed by the City of Samarinda Trade Office are Rp. 6,58 Billion/ year. Potential Sales Retribution in Traditional Market Environments of Rp. 1,34 Billion/year. In accordance with the results of the survey and interviews, three main obstacles were found which made the collection of market retribution not optimal, namely weather constraints, traders not selling and poor infrastructure.
\end{abstract}

Keywords: Regional original revenue; market service retribution; selling place usage retribution in traditional market environment 


\section{PENDAHULUAN}

Seiring dengan diberlakukannya otonomi daerah, maka kewenangan urusan pemerintahan dilimpahkan dari sebelumnya oleh Pemerintah Pusat Kepada Pemerintah Daerah. Hal ini tertuang di dalam Undang-Undang Nomor 23 Tahun 2014 tentang Pemerintahan Daerah dan Undang-Undang Nomor 33 Tahun 2004 tentang Perimbangan Keuangan Antara Pemerintah Pusat dan Pemerintahan Daerah.

Begitu pula mengenai urusan keuangan. pemerintah daerah dituntut untuk bisa mengelola keuangannya sendiri dan mencari sumber-sumber pendanaan untuk membiayai pemerintahannya agar tetap bisa terus berjalan. Sumber-sumber pembiayaan yang bisa diterima dan dikelola oleh Pemerintah Daerah berasal dari pajak daerah dan retribusi daerah. Kemampuan pemerintah daerah untuk menyerap retribusi daerah merupakan salah satu upaya daerah guna melaksanakan otonomi daerah. (Anggraini, Saifi, \& Husaini, 2015:2).

Sesuai dengan Undang-Undang Nomor 28 Tahun 2009 mengenai tentang Pajak Daerah dan Retribusi Daerah, sumber-sumber penerimaan daerah ada yang berasal dari dana bagi hasil dengan Pemerintah Pusat dan ada yang dihasilkan oleh pemerintah daerah sendiri yang biasa disebut Pendapatan Asli Daerah (PAD). Pendapatan Asli Daerah berupa Pajak Daerah dan Retribusi Daerah. Sesuai aturan tersebut Pajak Daerah adalah kontribusi wajib kepada Daerah yang terutang oleh orang pribadi atau badan yang bersifat memaksa berdasarkan Undang-Undang, dengan tidak mendapatkan imbalan secara langsung dan digunakan untuk keperluan Daerah bagi sebesar-besarnya kemakmuran rakyat. Sedangkan Retribusi Daerah adalah pungutan daerah sebagai pembayaran atas jasa atau pemberian izin tertentu yang khusus disediakan dan/atau diberikan oleh pemerintah daerah untuk kepentingan orang pribadi atau badan. Komponen Pajak Daerah meliputi Pajak Provinsi dan Pajak Kabupaten/Kota sedangkan komponen Retribusi Daerah meliputi Retribusi Jasa Umum, Retribusi Jasa Usaha dan Retribusi Perizinan Tertentu. Berdasarkan aturan itulah, pemerintah daerah dapat menarik retribusi di daerahnya secarah sah. Pemerintah daerah perlu untuk lebih meningkatkan secara maksimal penerimaan retribusi daerah agar kontribusi Pendapatan Asli Daerah meningkat (Mardiasmo, 2011:1).

Penelitian Mubarok 2016, menunjukkan bahwa perhitungan potensi retribusi pelayanan pasar Kota Samarinda berdasarkan Peraturan Daerah Nomor 13 Tahun 2011 Tentang Retribusi Jasa Umum dalam setahun menunjukkan potensinya yang sangat besar, namun realisasi pendapatan retribusi pelayanan pasar di lima tahun terakhir masih belum melampaui total potensi yang ada. Selain itu kontribusi dari retribusi pelayanan pasar terhadap pendapatan asli daerah Kota Samarinda pada indikator sangat kurang atau mengalami penurunan kontribusi di setiap tahunnya. Begitu pula prospek retribusi pelayanan pasar Kota Samarinda menunjukkan prospeknya yang positif (meningkat) selama lima tahun dimasa yang akan datang.

Penelitian Putri 2013, mendapatkan hasil yaitu faktor pendukung dalam pemungutan retribusi pasar di Pasar Pagi adalah adanya kerja sama antara Dinas Pasar dan Dispenda dalam pengelolaan pemungutan retribusi pasar pagi. Sedangkan faktor penghambat selama pemungutan retribusi dilaksanakan adalah tempat atau lokasi yang dikelola kurang baik karena masih banyak tempat yang sering terkena banjir pada saat cuaca buruk dan ini menyebabkan para petugas pemungut retribusi pun kesulitan dalam menjangkau tempat tersebut.

Berkaitan dengan pasar terdapat dua jenis retribusi yang bisa dihasilkan di Kota Samarinda, yaitu Retribusi Umum yang berasal dari Retribusi Pelayanan Pasar dan Retribusi Jasa Usaha yang berasal dari Retribusi Pemakaian Tempat Berjualan di Lingkungan Pasar Tradisional. Hal tersebut diatur dalam Peraturan Daerah Kota Samarinda Nomor 2 Tahun 2016 Tentang Perubahan Atas Peraturan Daerah Nomor 13 Tahun 2011 Tentang Retribusi Jasa Umum dan Peraturan Daerah Kota Samarinda Nomor 11 Tahun 2016 Tentang Perubahan Atas Peraturan Daerah Nomor 14 Tahun 2011 Tentang Retribusi Jasa Usaha. Kedua jenis retribusi tersebut merupakan sumber penerimaan yang penting dan sah terutama sumbangsihnya terhadap Pendapatan Asli Daerah terutama Kota Samarinda sebagai Kota Perdagangan dan Jasa, namun hingga saat ini belum dilakukan perhitungan sehingga potensi retribusi pelayanan pasar dan retribusi pemakaian tempat berjualan di pasar tradisional belum diketahui. Selain itu adanya penambahan jumlah unit pasar di bawah naungan Dinas Perdagangan Kota Samarinda menjadi 12 (dua belas) unit pasar. 
Tabel 1. Perbandingan Realisasi Retribusi Pelayanan Pasar Terhadap Pendapatan Asli Daerah dan Retribusi Daerah di Kota Samarinda Tahun 2012-2017 (Miliar Rupiah)

\begin{tabular}{ccccccc}
\hline Tahun & $\begin{array}{c}\text { Retribusi Jasa } \\
\text { Umum }\end{array}$ & $\begin{array}{c}\text { Retribusi } \\
\text { Pelayanan Pasar }\end{array}$ & \% & Retribusi Daerah & $\begin{array}{c}\text { Retribusi } \\
\text { Pelayanan Pasar }\end{array}$ & \% \\
\hline 2012 & 12,673 & 3.230 & 25,49 & 56,956 & 3,230 & 5,68 \\
2013 & 12,790 & 3.491 & 27,29 & 55,667 & 3,491 & 6,27 \\
2014 & 26,292 & 3.677 & 13,99 & 66,908 & 3,677 & 5,50 \\
2015 & 17,033 & 3.661 & 21,49 & 61,938 & 3,661 & 5,91 \\
2016 & 28,827 & 3.799 & 13,18 & 70,953 & 3,799 & 5,35 \\
2017 & 35,532 & 4.592 & 12,92 & 69,405 & 4,592 & 6,62 \\
\hline
\end{tabular}

Sumber: Badan Pendapatan Daerah Kota Samarinda (2018) (Diolah)

Berdasarkan tabel 1, Komposisi Retribusi Pelayanan Pasar dalam Retribusi Jasa Umum antara tahun 2012-2017 berfluktuatif dengan trend mengalami penurunan. Dari Tahun 2012 komposisinya sebesar 25,49 persen turun menjadi 12,92 persen pada tahun 2017. Komposisi terbesar terjadi pada tahun 2013 yaitu sebesar 27,29 persen sedangkan komposisi terendah terjadi pada tahun 2016 sebesar 13,18 persen. Sedangkan komposisi Retribusi Pelayanan Pasar terhadap Retribusi Daerah antara tahun 20122017 berfluktuatif dengan trend mengalami peningkatan. Dari Tahun 2012 komposisinya sebesar 5,67 persen naik menjadi 6,62 persen pada tahun 2017. Komposisi terbesar pada tahun 2017 yaitu sebesar 6,62 persen sedangkan komposisi terendah terjadi pada tahun 2016 yaitu sebesar 5,35 persen.

Adapun kedua belas unit pasar di Kota Samarinda yang dikelola oleh 3 (tiga) Unit Pelaksana Teknis Daerah (UPTD) Dinas Perdagangan Kota Samarinda, yaitu UPTD Pasar Segiri yang mengelola Pasar Segiri, Pasar Merdeka, Pasar Ijabah, Pasar Kedondong, Pasar Bengkuring, Pasar Lok Bahu. UPTD Pasar Pagi yang mengelola Pasar Pagi, Pasar Sungai Dama, Pasar Palaran, Pasar Baqa dan Pasar Kemuning. Sedangkan UPTD yang ketiga adalah UPTD Citra Niaga yang mengelola Kawasan Citra Niaga.

Dalam pelaksanaan pemungutan Retribusi Pelayanan Pasar, Dinas Perdagangan Kota Samarinda menggunakan karcis yang didistribusikan kepada 12 pasar. Setelah itu dilakukan pemungutan oleh juru tagih kepada Ruko (Rumah Toko), Kios, Lapak, Los di tiap pasar yang hasilnya lalu disetorkan kembali kepada Dinas Perdagangan Kota Samarinda. Sedangkan untuk retribusi Pemakaian Kekayaan Daerah dengan objek tempat berjualan di lingkungan pasar tradisional belum pernah dilakukan pemungutan. Hal ini disebabkan karena belum pernah adanya sosialisasi mengenai Peraturan Daerah Kota Samarinda Nomor 11 Tahun 2016 Tentang Perubahan Atas Peraturan Daerah Nomor 14 Tahun 2011 Tentang Retribusi Jasa Usaha dan meleburnya instansi Dinas Pasar Kota Samarinda ke dalam Dinas Perdagangan Kota Samarinda.

Setiap tahun Pemerintah Kota Samarinda memiliki target yang ingin dicapai dari penerimaan retribusi pelayanan pasar tersebut. Target yang ditetapkan merupakan hasil realisasi dari penerimaan retribusi pelayanan pasar pada tahun sebelumnya. Seharusnya target yang ditetapkan oleh Pemerintah Kota Samarinda harus melihat dari potensi dari kios, petak dan los serta pedagang kaki lima yang berjualan di pasar tersebut.

Hal ini disebabkan karena belum diketahuinya potensi penerimaan yang berasal dari retribusi pelayanan pasar dan juga potensi yang berasal dari retribusi jasa usaha. Dengan diketahuinya potensi penerimaan dari retribusi pasar maka Pemerintah Kota Samarinda akan dapat memaksimalkan target penerimaan retribusi pasar sehingga dapat meningkatkan Pendapatan Asli Daerah.

Berdasarkan akan hal tersebut maka permasalahan dari kajan ini adalah sebagai berikut.

Belum teridentifikasinya kontribusi penerimaan dari retribusi pasar meliputi Retribusi Pelayanan Pasar dan Retribusi Pemakaian Tempat Berjualan di Lingkungan Pasar Tradisional terhadap Pendapatan Asli Daerah Kota Samarinda.

Belum teridentifikasinya potensi penerimaan dari retribusi pasar meliputi Retribusi Pelayanan Pasar dan Retribusi Pemakaian Tempat Berjualan di Lingkungan Pasar Tradisional.

Belum teridentifikasinya hambatan dalam pemungutan retribusi pasar di kawasan pasar Kota Samarinda. 

Samarinda.

Belum adanya solusi bagi hambatan dalam pemungutan retribusi pasar di Kawasan pasar Kota

\section{METODE}

Metode penelitian yang digunakan adalah metode penelitian deskriptif evaluatif, di mana dalam penelitian ini hanya mendeskripsikan fakta-fakta yang ditemukan di lapangan tanpa mengadakan perubahan pada masing-masing variabel penelitian. Penelitian deskriptif, merupakan gambaran atau lukisan secara sistematis, faktual dan akurat mengenai fenomena atau hubungan antar fenomena yang diselidiki (Suprayogo dan Tobroni, 2001). Pendekatan yang digunakan dalam penelitian adalah pendekatan evaluatif, dimana peneliti bermaksud mengumpulkan data tentang implementasi kebijakan yang sudah dilakukan. (Arikunto, 2001).

Penelitian evaluatif pada dasarnya terpusat pada rekomendasi akhir yang menegaskan bahwa suatu obyek evaluasi dapat dipertahankan, ditingkatkan, diperbaiki atau bahkan diberhentikan sejalan dengan data yang diperoleh. Penggunaan metode dan pendekatan ini berangkat dari tujuan pokok penelitian yaitu mendeskripsikan proses pemungutan retribusi pasar di Kota Samarinda.

Untuk memperoleh data yang diperlukan, dilakukan pengamatan, wawancara, dokumentasi dan studi kepustakaan. Wilayah penelitian ini merupakan Kawasan pasar yang dikelola langsung oleh Dinas Perdagangan Kota Samarinda. Ada 12 (dua belas) pasar yang dikelola langsung yaitu Pasar Segiri, Pasar Pagi, Pasar Citra Niaga, Pasar Merdeka, Pasar Ijabah, Pasar Kedondong, Pasar Palaran, Pasar Baqa, Pasar Kemuning, Pasar Bengkuring, Pasar Sei Dama dan Pasar Lok Bahu. Informan yang digunakan adalah 2 (dua) informan dari Badan Pendapatan Daerah Kota Samarinda, 13 (tiga belas) informan dari Dinas Perdagangan Kota Samarinda dan 1 (satu) orang informan dari pedagang pasar.

Metode yang digunakan untuk menganalisis hasil penelitian ini adalah statistik deskriptif. Metode ini menguji dan menilai setiap data yang berhasil dikumpulkan dengan menggunakan alat analisis sebagai berikut:

\section{Analisis Tingkat Kontribusi}

Analisis Kontribusi yaitu suatu alat analisis yang digunakan untuk mengukur besarnya kontribusi yang diberikan oleh retribusi Penerimaan Pelayanan Pasar kepada Pendapatan Asli Daerah Kota Samarinda. Analisis ini dengan membandingkan antara jumlah realisasi Retribusi Pelayanan Pasar dengan jumlah Realisasi Pendapatan Asli Daerah secara keseluruhan. Adapun kriteria kontribusi Retribusi Pelayanan Pasar adalah sebagai berikut:

Tabel 2. Kriteria Kontribusi Retribusi Pelayanan Pasar

\begin{tabular}{ccc}
\hline No. & Persentase & Kriteria \\
\hline 1. & $0,00 \%-10 \%$ & Sangat Kurang \\
2. & $10,10 \%-20 \%$ & Kurang \\
3. & $20,10 \%-30 \%$ & Sedang \\
4. & $30,10 \%-40 \%$ & Cukup Baik \\
5. & $40,10 \%-50 \%$ & Baik \\
6. & $>50 \%$ & Sangat Baik \\
\hline
\end{tabular}

Sumber: Kemendagri Nomor 690.900.327

\section{Analisis Potensi Pasar}

Analisis potensi pasar adalah suatu alat analisis yang digunakan untuk mengukur besarnya potensi pasar dalam menghasilkan penerimaan retribusi pasar terhadap Pendapatan Asli Daerah Kota Samarinda. Perhitungan ini bertujuan untuk mengetahui besaran potensi Retribusi Pelayanan Pasar dan Retribusi Pemakaian Tempat Berjualan di Pasar Tradisional yang dikelola oleh Dinas Perdagangan Kota Samarinda. Adapun rumus dasar perhitungan potensi Retribusi Pelayanan Pasar selama setahun adalah sebagai berikut:

Potensi $=\left[\left(\sum\right.\right.$ Ruko $\mathrm{x}$ Luas $\mathrm{x}$ trf $)+\left(\sum\right.$ Kios $\left.\mathrm{x} \operatorname{trf}\right)+\left(\sum\right.$ Petak $\left.\mathrm{x} \operatorname{trf}\right)+\left(\sum\right.$ Los $\left.\mathrm{x} \operatorname{trf}\right)+\left(\sum\right.$ PKL $\left.\left.\mathrm{x} \operatorname{trf}\right)\right] \mathrm{x}$ [SAktivitas Pasar Perbulan $\mathrm{x}$ 12]

Keterangan

Ruko : Rumah Toko

PKL : Pedagang Kaki Lima 
Luas : Merupakan ukuran dari ruko $(\mathrm{m} 2)$

trf $\quad$ : Tarif (Rp. 3000,- untuk Kios/Petak/Los; dan Rp. 2000,- untuk PKL)

Sedangkan untuk potensi Retribusi Pemakaian Tempat Berjualan di Lingkungan Pasar Tradisional selama setahun dibagi menjadi dua, yaitu:

\section{Untuk Pasar Kelas I}

Potensi $=\left[\left(\sum\right.\right.$ Kios/Petak $x$ Luas $\left.x \operatorname{trf}\right)+\left(\sum\right.$ Los $x$ Luas $\left.\left.x \operatorname{trf}\right)\right] \mathrm{x} 12$

Keterangan

Luas : Merupakan ukuran Kios/Petak/Los (m2)

trf $\quad$ : Tarif (Rp. 20.000,- untuk Kios/Petak; Rp. 15.000,- untuk Los)

\section{Untuk Pasar Kelas II}

Potensi $=\left[\left(\sum\right.\right.$ Kios $/$ Petak $\mathrm{x}$ trf $)+\left(\sum \operatorname{Los} \mathrm{x}\right.$ trf $\left.)\right] \mathrm{x} 12$

Keterangan

trf $\quad$ : Tarif (Rp. 17.000,- untuk Kios/Petak; Rp. 15.000,- untuk Los)

Untuk petak/kios/los yang sudah digunakan sebelum Peraturan Daerah Nomor 11 Tahun 2016 diberlakukan, maka berlaku tarif retribusi sebesar 50 persen dari tarif yang berlaku.

\section{HASIL DAN PEMBAHASAN}

\section{Analisis Kontribusi Retribusi Pasar di Kota Samarinda}

Kontribusi digunakan untuk mengetahui sejauh mana pajak daerah memberikan sumbangan dalam penerimaan Pendapatan Asli Daerah. Semakin besar hasilnya berarti semakin besar pula peranan pajak daerah terhadap Pendapatan Asli Daerah, begitu pula sebaliknya jika hasil perbandingannya terlalu kecil berarti peranan pajak daerah terhadap Pendapatan Asli Daerah juga kecil (Mahmudi, 2010:145 dalam Memah, 2013:877). Analisis ini dengan membandingkan antara jumlah realisasi Retribusi Pelayanan Pasar dengan jumlah Realisasi Pendapatan Asli Daerah secara keseluruhan. Adapun hasil dari analisis kontribusi Retribusi Pelayanan Pasar di Kota Samarinda adalah sebagai berikut:

Tabel 3. Hasil Analisis Kontribusi Retribusi Pelayanan Pasar

\begin{tabular}{ccccc}
\hline Tahun & PAD & Retribusi Pelayanan Pasar & $\mathbf{\%}$ & Kriteria \\
\hline 2012 & 263,902 & 3,230 & 1.22 & Sangat Kurang \\
2013 & 338,199 & 3,491 & 1.03 & Sangat Kurang \\
2014 & 435,493 & 3,677 & 0.84 & Sangat Kurang \\
2015 & 408,195 & 3,661 & 0.90 & Sangat Kurang \\
2016 & 391,478 & 3,799 & 0.97 & Sangat Kurang \\
2017 & 517,499 & 4,592 & 0.89 & Sangat Kurang \\
\hline Sumber: Kemendagri Nomor $690.900 .327 ;$ Bapenda $(2018)($ diolah) &
\end{tabular}

Sumber: Kemendagri Nomor 690.900.327; Bapenda (2018) (diolah)

Berdasarkan hasil perhitungan analisis kontribusi sesuai dengan Tabel 3 diatas dapat diambil kesimpulan bahwa antara tahun 2012-2017 kontribusi Retribusi Pelayanan Pasar terhadap Pendapatan Asli Daerah Kota Samarinda memiliki kriteria Sangat Kurang karena nilainya masih dibawah 10 persen. Untuk itu masih diperlukan upaya-upaya yang signifikan untuk meningkatkan Retribusi Pelayanan Pasar di Kota Samarinda.

Untuk analisis kontribusi Retribusi Pemakaian Kekayaan Daerah dengan objek Retribusi Tempat Berjualan Di Pasar Tradisional belum dapat dihitung karena belum dilakukan pemungutan.

Tipe pasar merupakan suatu penggolongan jenis pasar berdasarkan besar kecilnya pasar dan banyak sedikitnya penghasilan dari realisasi retribusi pelayanan pasar tersebut. Tipe pasar mempengaruhi besar kecilnya pembayaran retribusi pelayanan pasar. Karena besarnya retribusi suatu pasar ditentukan oleh tipe dari pasar tersebut. Sedangkan potensi adalah daya, kekuatan atau kesanggupan untuk menghasilkan penerimaan daerah atau kemampuan yang pantas diterima dalam keadaan seratus persen yang meliputi jumlah ruko, kios, petak, los yang terdapat di pasar dan dikelola oleh pemerintah daerah (Haryono, 2012:6).

Berdasarkan Peraturan Daerah Kota Samarinda Nomor 2 Tahun 2016 Tentang Perubahan Atas Peraturan Daerah Nomor 13 Tahun 2011 Tentang Retribusi Jasa Umum Pasal 32 mengatur klasifikasi, struktur dan besarnya tarif retribusi pelayanan pasar di Kota Samarinda. Di dalam peraturan tersebut mengatur besarnya tarif retribusi pelayanan pasar tergantung dari tipe dan potensi masing-masing pasar 
dan tarif retribusi ini untuk pelayanan jasa kebersihan dan keamanan. Tarif retribusi dikenakan bagi seluruh pedagang yang menggunakan fasilitas ruko, kios, petak, los dan emperan/pedagang kaki lima. Adapun besaran tarif retribusi pelayanan pasar seperti pada tabel 4 di bawah ini:

Tabel 4. Tarif Retribusi Pelayanan Pasar Berdasarkan Tipe Pasar di Kota Samarinda Berdasarkan Peraturan Daerah Nomor 2 Tahun 2016 (Rupiah)

\begin{tabular}{clc}
\hline Tipe & \multicolumn{1}{c}{ Fasilitas } & Tarif \\
\hline \multirow{2}{*}{ Tipe A1 } & Ruko & $150 / \mathrm{m} 2$ \\
& Kios/Petak/Los & 3.000 \\
& Emperan/PKL & 2.000 \\
Tipe A2 & Ruko & $125 / \mathrm{m} 2$ \\
& Kios/Petak/Los & 3.000 \\
& Emperan/PKL & 2.000 \\
Tipe B1 & Ruko & $100 / \mathrm{m} 2$ \\
& Kios/Petak/Los & 3.000 \\
& Emperan/PKL & 2.000 \\
Tipe B2 & Ruko & $100 / \mathrm{m} 2$ \\
& Kios/Petak/Los & 3.000 \\
& Emperan/PKL & 2.000 \\
Tipe D & Kios/Petak/Los & 2.000 \\
& Emperan/PKL & 2.000 \\
\hline
\end{tabular}

Sumber: Dinas Perdagangan Kota Samarinda (2018)

Tipe pasar yang dikelola pemerintah daerah di Kota Samarinda terbagi atas Tipe A (A1 dan A2) dan Tipe B (hanya tipe B2). Dari 12 pasar di Kota Samarinda, hanya Pasar Pagi dan Pasar Segiri yang bertipe A1. Pembagian tipe pasar ini berdasarkan ukuran besar kecilnya pasar dan besarnya realisasi pendapatan retribusi pelayanan pasar serta lokasi.

Untuk jumlah kios/petak/los terbanyak berada di Pasar Pagi dengan jumlah sebanyak 1551 unit. Sedangkan ruko (rumah toko) terbanyak terdapat pada Pasar Citra Niaga dengan jumlah sebanyak 150 Unit. Selain itu untuk Pedagang Kaki Lima (PKL) jumlah terbanyak berada di Pasar Pagi dengan jumlah 548 orang seperti pada tabel 5 di bawah ini.

Tabel 5. Jumlah Fasilitas Pasar di Kota Samarinda

\begin{tabular}{lcccc}
\hline \multirow{2}{*}{ Nama Pasar } & Tipe & \multicolumn{3}{c}{ Fasilitas } \\
\cline { 3 - 5 } & Pasar & Ruko & Kios/Petak/Los & PKL \\
\hline Pasar Pagi & Tipe A1 & 10 & 1,551 & 548 \\
Pasar S. Dama & Tipe B2 & 76 & 285 & 28 \\
Pasar Palaran & Tipe A2 & - & 228 & 30 \\
Pasar Baqa & Tipe A2 & - & 175 & 100 \\
Pasar Kemuning & Tipe A2 & - & 145 & - \\
Pasar Segiri & Tipe A1 & 146 & 532 & 254 \\
Pasar Merdeka & Tipe A2 & 32 & 348 & - \\
Pasar Ijabah & Tipe A2 & - & 443 & - \\
Pasar Kedondong & Tipe A2 & - & 296 & - \\
Pasar Bengkuring & Tipe A2 & - & 44 & - \\
Pasar Lok Bahu & Tipe B2 & - & 141 & - \\
Citra Niaga & Tipe A2 & 150 & 400 & \\
\hline Sumber: Dinas Perdagangan Kota Samind
\end{tabular}

Sumber: Dinas Perdagangan Kota Samarinda (2018)

Dari potensi semua pasar yang dikelola Pemerintah Kota Samarinda maka dapat disimpulkan dari total potensi keseluruhan pasar yang dikelola Pemerintah Kota Samarinda merupakan total potensi retribusi pelayanan pasar di Kota Samarinda. Total potensi retribusi pelayanan pasar tersebut terbagi atas dua komponen yaitu retribusi kebersihan dan retribusi keamanan.

Untuk menghitung jumlah potensi Retribusi Pelayanan Pasar yang ada di 12 pasar Kota Samarinda maka digunakan rumus dasar penghitungan potensi retribusi pasar umum selama setahun. Adapun hasil dari perhitungan tersebut adalah sebagai berikut ini. 
Tabel 6. Potensi Retribusi Pelayanan Pasar di Kota Samarinda Pertahun (Rupiah)

\begin{tabular}{lccccc}
\hline \multirow{2}{*}{ Nama Pasar } & \multicolumn{5}{c}{ Potensi Retribusi Pelayanan Pasar } \\
\cline { 2 - 6 } & $\begin{array}{c}\text { Total Potensi } \\
\text { Ruko }\end{array}$ & $\begin{array}{c}\text { Total Potensi } \\
\text { Kios/Petak/Los }\end{array}$ & $\begin{array}{c}\text { Total Potensi } \\
\text { PKL }\end{array}$ & $\begin{array}{c}\text { Total } \\
\text { Keseluruhan }\end{array}$ & $\%$ \\
\hline Pasar Pagi & $16,632,000$ & $1,675,080,000$ & $394,560,000$ & $2,086,272,000$ & 31.70 \\
Pasar S. Dama & $73,872,000$ & $307,800,000$ & $20,160,000$ & $401,832,000$ & 6.11 \\
Pasar Palaran & - & $246,240,000$ & $21,600,000$ & $267,840,000$ & 4.07 \\
Pasar Baqa & - & $189,000,000$ & $72,000,000$ & $261,000,000$ & 3.97 \\
Pasar Kemuning & - & $156,600,000$ & - & $156,600,000$ & 2.38 \\
Pasar Segiri & $192,240,000$ & $574,560,000$ & $182,880,000$ & $949,680,000$ & 14.43 \\
Pasar Merdeka & $108,000,000$ & $375,840,000$ & - & $483,840,000$ & 7.35 \\
Pasar Ijabah & - & $478,440,000$ & - & $478,440,000$ & 7.27 \\
Pasar Kedondong & - & $319,680,000$ & $59,760,000$ & $379,440,000$ & 5.76 \\
Pasar Bengkuring & - & $47,520,000$ & - & $47,520,000$ & 0.72 \\
Pasar Lok Bahu & - & $152,280,000$ & - & $152,280,000$ & 2.31 \\
Citra Niaga & $485,100,000$ & $432,000,000$ & - & $917,100,000$ & 13.93 \\
\hline \multicolumn{7}{c}{ Total } & & & & $\mathbf{6 , 5 8 1 , 8 4 4 , 0 0 0}$ & $\mathbf{1 0 0}$ \\
\hline
\end{tabular}

Sumber: Dinas Perdagangan Kota Samarinda dan Hasil Survei (2018)

Dari tabel 6 terlihat bahwa potensi retribusi pelayanan pasar di Kota Samarinda pertahun adalah sebesar Rp. 6.581.844.000,-. Potensi terbesar terdapat di Pasar Pagi dengan jumlah 10 Ruko, 1551 Kios/Petak/Los dan PKL yang berjumlah 548 yang menghasilkan total retribusi pelayanan pasar pertahun sebesar Rp. 2.086.272.000,- atau sebesar 31,70 persen terhadap total potensi retribusi pelayanan pasar di Kota Samarinda. Potensi terbesar kedua terdapat di Pasar Segiri dengan jumlah 146 Ruko, 532 Kios/Petak/Los dan 254 PKL yang menghasilkan retribusi pelayanan pasar sebesar Rp. 949.680.000,- atau sebesar 14,43 persen. Sedangkan potensi retribusi pelayanan pasar terkecil terdapat di Pasar Kedondong dengan jumlah $44 \mathrm{Kios} / \mathrm{Petak} /$ Los yang menyumbang potensi retribusi pelayanan pasar sebesar Rp. 47.520.000,- atau sebesar 0,72 persen terhadap total potensi retribusi pelayanan pasar di Kota Samarinda.

Selain retribusi pelayanan pasar, sesuai dengan Peraturan Daerah Kota Samarinda Nomor 11 Tahun 2016 Tentang Perubahan Atas Peraturan Daerah Nomor 14 Tahun 2011 Tentang Retribusi Jasa Usaha juga dipungut Retribusi Pemakaian Kekayaan Daerah dengan objek retribusi yaitu tempat berjualan di lingkungan pasar tradisional. Di dalam peraturan tersebut fasilitas yang dikenakan retribusi adalah petak/kios dan los. Untuk pembagian struktur pasar dalam peraturan tersebut berdasarkan kelas. Untuk pasar Kelas I seperti Pasar Segiri dan Pasar Pagi dikenakan biaya sewa sesuai jumlah kepemilikan dan luas petak/kios dan los selama satu bulan. Sedangkan untuk Kelas II seperti Pasar Sungai Dama, Pasar Merdeka, Pasar Citra Niaga, Pasar Baqa, Pasar Palaran, Pasar Ijabah, Pasar Kedondong, dan Pasar Kemuning dengan tarif retribusi dihitung berdasarkan jumlah kepemilikan petak/kios dan los seperti pada tabel di bawah ini.

Tabel 7. Tarif Retribusi Pemakaian Kekayaan Daerah Dengan Objek Retribusi Pemakaian Tempat Berjualan di Lingkungan Pasar Tradisional Berdasarkan Peraturan Daerah Kota Samarinda Nomor 11 Tahun 2016 Tentang Perubahan Atas Peraturan Daerah Nomor 14 Tahun 2011 Tentang Retribusi Jasa Usaha (Rupiah)

\begin{tabular}{|c|c|c|c|c|c|}
\hline \multirow{2}{*}{$\begin{array}{l}\text { Lokasi } \\
\text { Pasar }\end{array}$} & \multirow{2}{*}{$\begin{array}{c}\text { Jenis } \\
\text { Fasilitas }\end{array}$} & \multicolumn{3}{|c|}{ Besarnya Tarif } & \multirow[b]{2}{*}{ Keterangan } \\
\hline & & Lantai I & $\begin{array}{c}\text { Lantai } \\
\text { II }\end{array}$ & Lantai III & \\
\hline \multirow[t]{2}{*}{ Kelas I } & Petak/Kios & 25.000 & 20.000 & 18.000 & Sewa/Bulan/m² \\
\hline & Los & 20.000 & 15.000 & 15.000 & Sewa/Bulan/m² \\
\hline \multirow[t]{2}{*}{ Kelas II } & Petak/Kios & 20.000 & 17.000 & 15.000 & Sewa/Bulan/Petak \\
\hline & Los & 18.000 & 15.000 & 12.000 & Sewa/Bulan/Los \\
\hline
\end{tabular}




\begin{tabular}{lllllc}
\hline Kelas III & Petak/Kios & 18.000 & 15.000 & 12.000 & Sewa/Bulan/Petak \\
& Los & 15.000 & 12.000 & 10.000 & Sewa/Bulan/Los \\
\hline
\end{tabular}

Keterangan:

Tarif sewa tidak termasuk biaya listrik petak/kios/los

Untuk petak/kios/los yang sudah digunakan sebelum perda ini diundangkan, maka berlaku tarif retribusi sebesar 50\% (lima puluh persen) dari tarif yang berlaku dalam perda ini.

Sumber: Dinas Perdagangan Kota Samarinda (2018)

Adapun perhitungan potensi berdasarkan tarif retribusi pemakaian tempat berjualan di pasar rakyat sesuai dengan tabel 8 di bawah ini.

Tabel 8. Potensi Retribusi Pemakaian Kekayaan Daerah Dengan Objek Retribusi Tempat Berjualan Di Pasar Tradisional Berdasarkan Peraturan Daerah Kota Samarinda Nomor 11 Tahun 2016 Tentang Perubahan Atas Peraturan Daerah Nomor 14 Tahun 2011 Tentang Retribusi Jasa Usaha

\begin{tabular}{|c|c|c|c|c|c|c|}
\hline \multirow{2}{*}{$\begin{array}{l}\text { Nama Pasar } \\
\text { Pasar Pagi }\end{array}$} & \multicolumn{2}{|c|}{ Kios/Petak/Los } & \multirow{2}{*}{$\begin{array}{c}\begin{array}{c}\text { Luas } \\
(\mathbf{m} 2)\end{array} \\
5\end{array}$} & \multirow{2}{*}{$\begin{array}{c}\text { Tarif } \\
10,000\end{array}$} & \multirow{2}{*}{$\begin{array}{r}\begin{array}{r}\text { Waktu } \\
\text { (bulan) }\end{array} \\
12\end{array}$} & \multirow{2}{*}{$\begin{array}{c}\text { Jumlah } \\
895,800,000\end{array}$} \\
\hline & Kios/Petak & 1,493 & & & & \\
\hline & Los & 58 & 2 & 7,500 & 12 & $7,830,000$ \\
\hline Pasar S. Dama & Kios/Petak & 285 & - & 8,500 & 12 & $29,070,000$ \\
\hline Pasar Palaran & Los & 228 & - & 7,500 & 12 & $20,520,000$ \\
\hline Pasar Baqa & Los & 175 & - & 7,500 & 12 & $15,750,000$ \\
\hline \multirow[t]{2}{*}{ Pasar Kemuning } & Kios/Petak & 110 & - & 8,500 & 12 & $11,220,000$ \\
\hline & Los & 35 & - & 7,500 & 12 & $3,150,000$ \\
\hline \multirow[t]{2}{*}{ Pasar Segiri } & Kios/Petak & 111 & 4 & 10,000 & 12 & $53,280,000$ \\
\hline & Los & 421 & 4 & 7,500 & 12 & $151,560,000$ \\
\hline Pasar Merdeka & Los & 348 & - & 7,500 & 12 & $31,320,000$ \\
\hline Pasar Ijabah & Los & 443 & - & 7,500 & 12 & $39,870,000$ \\
\hline Pasar Kedondong & Los & 296 & - & 7,500 & 12 & $26,640,000$ \\
\hline Pasar Bengkuring & Los & 44 & - & 7,500 & 12 & $3,960,000$ \\
\hline Pasar Lok Bahu & Los & 141 & - & 7,500 & 12 & $12,690,000$ \\
\hline Citra Niaga & Kios/Petak & 400 & - & 8,500 & 12 & $40,800,000$ \\
\hline Total & & 4,588 & & & & $1,343,460,000$ \\
\hline
\end{tabular}

Sumber: Hasil Survei (2018)

Berdasarkan tabel 8, dengan mengambil nilai tengah dari tiap kelas pasar maka diperoleh potensi untuk 12 pasar yang dikelola oleh Dinas Perdagangan Kota Samarinda berdasarkan Retribusi Pemakaian Kekayaan Daerah dengan objek tempat berjualan di pasar tradisonal sebesar Rp. 1.343.460.000,- per tahun. Potensi terbesar terdapat di Pasar Pagi sebesar Rp. 903.630.000,- per tahun dan potensi terkecil berada di Pasar Bengkuring sebesar Rp. 3.960.000,00,- per tahun.

Target retribusi pelayanan pasar yang ditentukan di Kota Samarinda dari tahun 2016-2018 ratarata terealisasi di tiap-tiap pasarnya. Dalam hal ini yakni retribusi pelayanan pasar, apabila target yang ditentukan berada di bawah potensi yang ada maka kemungkinan besar target akan terealisasi.

Tabel 9. Perbandingan Target dan Potensi Retribusi Pelayanan Pasar Kota Samarinda Tahun 20162018

\begin{tabular}{ccccccc}
\hline No. & Tahun & Target & Potensi & Keterangan & Kurang/Lebih & \% \\
\hline 1 & 2016 & $3,700,000,000$ & $6,571,044,000$ & Target $<$ Potensi & $-2,871,044,000$ & -44 \\
2 & 2017 & $4,500,000,000$ & $6,571,044,000$ & Target $<$ Potensi & $-2,071,044,000$ & -32 \\
3 & 2018 & $4,750,000,000$ & $6,571,044,000$ & Target $<$ Potensi & $-1,821,044,000$ & -28 \\
\hline
\end{tabular}

Sumber: Badan Pendapatan Daerah Kota Samarinda dan Pengolahan Data (2018)

Dari tabel 9. terlihat bahwa target yang ditentukan dari tahun 2016-2018 cenderung meningkat. Dari tahun 2016 yang targetnya sebesar Rp. 3.700.000.000,-- meningkat menjadi Rp. 4.500.000.000,- di 
tahun 2017 dan terus meningkat hingga tahun 2018 menjadi sebesar Rp. 4.750.000.000,-. Meski target yang ditentukan cenderung meningkat dari tahun 2016-2018, namun target retribusi pelayanan pasar selalu lebih kecil dibandingkan dengan potensi yang ada. Di tahun 2016 target retribusi masih rendah karena belum disesuaikannya tarif berdasarkan Peraturan Daerah Nomor 2 Tahun 2016. Akan tetapi di tahun 2017-2018 dengan target pertahun masing-masing sebesar Rp. 4.500.000.000,- dan Rp. 4.750.000.000,- masih terlalu kecil dibandingkan dengan potensi retribusi pelayanan pasar yang ada yakni sebesar Rp. 6.581.844.000,-. Pada tahun 2017 target Retribusi Pelayanan Pasar Samarinda masih kurang sebesar Rp. 2.071.044.000,- atau kurang sebesar 32 persen. Sedangkan target pada tahun 2018 target kurang sebesar Rp. 1.821.044.000,- atau kurang sebesar 28 persen.

\section{Hambatan Dalam Pemungutan Retribusi Pasar Di Kawasan Pasar Kota Samarinda.}

Dalam pemungutan retribusi pelayanan pasar di Kota Samarinda, terdapat hambatan yang mengakibatkan pemungutan tidak berjalan optimal dan penerimaan retribusi tidak mencapai target. Berdasarkan hasil survei setidaknya ada tiga hambatan utama yang menjadikan pemungutan retribusi pasar tidak optimal, yaitu:

Adanya kendala pada cuaca yang tidak mendukung. Ketika cuaca hujan, maka juru tagih tidak dapat melakukan penagihan karena kios/petak/los mengalami kebanjiran. Penagihan akan dilakukan ketika hujan reda. Hal ini didukung oleh (Putri, 2013: 519) yang menyebutkan tempat-tempat atau lokasi yang akan di datangi untuk melakukan penagihan mengalami kebanjiran karena dibagian lantai dasar sangat rendah datarannya dan sempit wilayahnya.

Pedagang tidak berjualan. Ketika pedagang tidak berjualan tentu saja tidak ada penagihan. Dengan tidak adanya penagihan maka potensi penerimaan menjadi berkurang.

Sarana dan prasarana pasar yang kurang baik. Maksudnya disini adalah dengan fasilitas pasar yang kurang baik seperti kios yang bocor, masalah drainase, dan banjir akan dijadikan alasan oleh pedagang untuk menunda ataupun membayar retribusi pelayanan pasar.

\section{Solusi Terhadap Hambatan Dalam Pemungutan Retribusi Pasar Di Kawasan Pasar Kota Samarinda.}

Dengan adanya hambatan-hambatan yang mengakibatkan retribusi pelayanan pasar di Kota Samarinda tidak berjalan optimal tentu dibutuhkan suatu solusi untuk mengatasinya. Untuk hambatan pertama dan kedua yaitu kendala cuaca dan pedagang yang tidak berjualan, salah satu solusi yang bisa dilaksanakan adalah penerapan e-retribusi yang dibayarkan setiap bulan. Sistem ini sudah banyak diterapkan di kota-kota di Pulau Jawa seperti Kota Surakarta, Kota Yogyakarta, Kota Semarang, Kabupaten Kendal, Kabupaten Banyuwangi dan Kabupaten Tegal.

E-retribusi merupakan sistem aplikasi retribusi pembayaran elektronik yang bekerjasama dengan perbankan. Diterapkannya e-retribusi untuk retribusi pelayanan pasar Kota Samarinda mempunyai tujuan sebagai berikut:

Salah satu solusi untuk meningkatkan penerimaan daerah.

Pembayaran retribusi lebih efisien, transparan dan tertib administrasi.

Penghematan biaya operasional dan petugas.

Mendukung percepatan penggunaan kartu sebagai alat transaksi nontunai dalam jumlah kecil sehingga beban negara untuk mencetak uang kartal berkurang.

Inovasi ini juga akan mendukung program untuk menjadikan Samarinda sebagai smart city.

Menumbuhkan budaya menabung di kalangan pedagang tradisional.

Pedagang, secara tidak langsung akan lebih dekat dengan kalangan perbankan. sehingga lebih mudah mengakses bantuan permodalan. berikut:

Sedangkan manfaat penerapan e-retribusi di kawasan pasar Kota Samarinda adalah sebagai

Mempermudah membayar retribusi.

Transaksi yang akuntabel.

Realtime Incoming Report.

Tidak adanya penyimpangan.

Meningkatkan Pendapatan Asli Daerah. 
Dalam penerapan e-retribusi terdapat-langkah-langkah yang harus dilakukan oleh Pemerintah Kota Samarinda agar sistem ini dapat dilaksanakan. Adapun langkah-langkah tersebut adalah sebagai berikut:

Menyiapkan landasan hukum pelaksanaan e-retribusi baik Peraturan Daerah dan Peraturan Walikota Samarinda.

Menyiapkan Perjanjian Kerjasama/Kesepakatan Bersama dengan pihak perbankan di Kota Samarinda. Menyiapkan dan memperbarui database pedagang pasar yang dikelola oleh Dinas Perdagangan Kota Samarinda.

Melakukan sosialisasi kepada asosiasi pedagang.

Melakukan sosialisasi kepada pedagang pasar.

Pelaksanaan sistem e-retribusi.

Pembayaran retribusi secara elektronik.

Monitoring dan Evaluasi pelaksanaan e-retribusi.

Apabila pedagang tidak berjualan selama lebih dari satu bulan (tanpa keterangan) atau tidak membayar retribusi maka dapat dievaluasi kepemilikan SKTUB (Surat Keterangan Tempat Usaha Berjualan)-nya sesuai dengan pernyataan yang telah dibuat oleh pedagang pasar agar bisa dialihkan kepada pasar yang lain.

Sedangkan untuk hambatan ketiga yaitu sarana dan prasarana yang kurang baik, solusi yang bisa diberikan adalah dengan menganggarkan biaya perbaikan dan pengadaan sarana dan prasarana pasar pada Dinas Perdagangan Kota Samarinda.

\section{SIMPULAN}

Adapun kesimpulan dari Kajian Identifikasi Potensi Dan Permasalahan Retribusi Pasar Dalam Rangka Peningkatan Pendapatan Asli Daerah Kota Samarinda adalah sebagai berikut ini.

Berdasarkan hasil perhitungan analisis kontribusi antara tahun 2012-2017, kontribusi Retribusi Pelayanan Pasar terhadap Pendapatan Asli Daerah Kota Samarinda memiliki kriteria Sangat Kurang karena nilainya masih dibawah 10 persen. Untuk itu masih diperlukan upaya-upaya yang signifikan untuk meningkatkan Retribusi Pelayanan Pasar di Kota Samarinda. Untuk analisis kontribusi Retribusi Tempat Berjualan Di Pasar Tradisional belum dapat dihitung karena belum dilakukan pemungutan.

Sesuai dengan Peraturan Daerah Kota Samarinda Nomor 2 Tahun 2016 Tentang Perubahan Atas Peraturan Daerah Nomor 13 Tahun 2013 Tentang Retribusi Jasa Umum, diketahui potensi Retribusi Pelayanan Pasar yang dikelola oleh Dinas Perdagangan Kota Samarinda adalah sebesar Rp. 6.581.844.000,--.per tahun.

Sesuai dengan Peraturan Daerah Kota Samarinda Nomor 11 Tahun 2016 Tentang Perubahan Atas Peraturan Daerah Nomor 14 Tahun 2011 Tentang Retribusi Jasa Usaha, maka dapat dipungut Retribusi Empat Berjualan Di Lingkungan Pasar Tradisional. Berdasarkan struktur dan tarif retribusi maka diperoleh potensi sebesar Rp. 1.343.460.000,- per tahun.

Sesuai dengan hasil survei dan wawancara maka diperoleh tiga hambatan utama yang menjadikan pemungutan retribusi pasar tidak optimal yaitu kendala cuaca, pedagang tidak berjualan dan sarana prasarana yang kurang baik.

Solusi yang bisa dilaksanakan dalam kajian ini adalah dengan penerapan e-retribusi dan perbaikan serta pengadaan sarana dan prasarana pasar di Dinas Perdagangan Kota Samarinda serta melakukan evaluasi terhadap kepemilikan SKTUB.

\section{DAFTAR PUSTAKA}

Anggraini, N. E., Saifi, M., \& Husaini, A. (2015). Analisis Efektifitas Retribusi Pelayanan Pasar Tanjung Dan Kontribusinya Terhadap Pendapatan Asli Daerah Kota Mojokerto. Jurnal Perpajakan (JEJAK), 1(1), 1-10.

Arikunto. (2001). Prosedur Penelitian : Suatu Pendekatan Praktek. Edisi Revisi V, Cetakan Keduabelas. Jakarta: Rineka Cipta.

Depdagri, Kemendagri Nomor. 690.900.327 Tahun 1996 tentang Pedoman Penilaian dan Kinerja Keuangan. 
Haryono, H. D. (2012). Analisis Potensi Retribusi Pelayanan Pasar Di Kabupaten Kendal. Economics Development Analysis Journal, 1(1), 295-303.

Mardiasmo.2011. Perpajakan. Edisi Revisi 2011. Yogyakarta: Andi Offset.

Memah, E. W. (2013). Efektivitas Dan Kontribusi Penerimaan Pajak Hotel Dan Restoran Terhadap PAD Kota Manado. Jurnal EMBA, 1(3), 871-881.

Mubarok, D. H. N. (2016). Potensi Penerimaan Retribusi Pelayanan Pasar Dan Kontribusi Serta Prospeknya Terhadap Pendapatan Asli Daerah Kota Samarinda. FORUM EKONOMI: Jurnal Ekonomi, Manajemen dan Akuntansi, 18(2), 95-110.

Pemerintah Kota Samarinda. (2018). Laporan Realisasi Pendapatan Daerah Kota Samarinda 2012-2017. Samarinda: Badan Pendapatan Daerah.

Pemerintah Kota Samarinda. (2016). Peraturan Daerah Kota Samarinda Nomor 2 Tahun 2016 Tentang Perubahan Atas Peraturan Daerah Nomor 13 Tahun 2011 Tentang Retribusi Jasa Umum. Samarinda.

Pemerintah Kota Samarinda. (2016). Peraturan Daerah Kota Samarinda Nomor 11 Tahun 2016 Tentang Perubahan Atas Peraturan Daerah Nomor 14 Tahun 2011 Tentang Retribusi Jasa Usaha. Samarinda.

Putri, P. W. (2013). Studi Tentang Evaluasi Penerimaan Retribusi Di Kantor UPTD Pasar Pagi Kota Samarinda. eJournal Administrasi Negara, 1(2), 507-521.

Republik Indonesia. (2014). Undang-Undang Nomor 23 tahun 2014 tentang Pemerintahan Daerah. Jakarta: Sekretariat Negara.

Republik Indonesia. (2014). Undang-Undang Nomor 33 tahun 2004 tentang Perimbangan Keuangan Antara Pemerintah Pusat dan Pemerintahan Daerah. Jakarta: Sekretariat Negara.

Republik Indonesia. (2009). Undang-Undang Nomor 28 tahun 2009 tentang Pajak Daerah dan Retribusi Daerah. Jakarta: Sekretariat Negara.

Suprayogo, Imam., Tobroni. (2001). Metode Penelitian Sosial Agama. Bandung: Remaja Rosdakarya. 